INTERNATIONAL JOURNAL OF MULTidisciplinARY RESEARCH AND ANALYSis

ISSN(print): 2643-9840, ISSN(online): 2643-9875

Volume 04 Issue 02 February 2021

DOI: 10.47191/ijmra/v4-i2-08, Impact Factor: 6.072

Page No.- 151-154

\title{
Study of Body Attitude Criteria of Indoor Hockey Players Based on Body Height to Obtain Accurate Shooting Techniques
}

\author{
TB Syarif Hidayattullah ${ }^{1}$, Hernawan ${ }^{2}$, Sri Nuraini ${ }^{3}$, Iwan Sugihartono ${ }^{4}$, Achmad Ainul Yaqin ${ }^{5}$, \\ Ramdan Pelana ${ }^{6}$ \\ 1,2,3,6 Physical Education, Universitas Negeri Jakarta, Indonesia \\ 4,5 Mathematics and Natural Science, Universitas Negeri Jakarta, Indonesia
}

ABSTRACT: The purpose of this study was to make a preliminary study of the criteria for accurate shooting techniques based on height. Researchers in this study analyzed an accurate ball shooting technique based on body posture consisting of the initial attitude, the execution attitude, and the final attitude. The posture of the ball shooting technique has been demonstrated by indoor hockey players at the Sports Science Faculty, Jakarta State University. The data obtained in this study were taken through observation, interviews, and filling out questionnaires. This study uses a qualitative method by distributing questionnaires to each player. The population used was the hockey athlete at the State University of Jakarta. The sample was taken in this study using a total sampling technique. The results of this study the respondents stated that playing experience, comfort, The body postures of the respondents support the ability to shoot the ball accurately, respectively, shown by the percentage strongly agree and agree are $45 \%$ and $44 \%, 52 \%$ and $44 \%, 70 \%$ and $30 \%$. Furthermore, for height, the largest percentage was $44 \%$ disagreed and $26 \%$ doubtful, for arm length the largest percentage was $45 \%$ doubtful and $41 \%$ disagreed. This means that height and arm length do not affect the respondent's accuracy in shooting the ball accurately. However, the distance between the hand grips affects the accuracy and comfort, this is reinforced by the percentage strongly agree and agree that the hand grip distance affects the accuracy is $19 \%$ and $59 \%$ and the distance between the handles based on comfort is $33 \%$ and $56 \%$. The results of this study will be given to athletes and coaches as evaluation material.

KEYWORDS: Indoor Hockey, Posture, Shooting, Height, Accuracy, Anthropometry.

\section{INTRODUCTION}

Hockey is a sport which is included in the sport that is competed in the highest multi-event events in the world, starting from the Olympics, Asian Games, SEA Games, and other championships including the National Sports Week. Hockey is a sport game that is carried out in teams / teams (Lestari \& Amin, 2019). Each player holds a stick (stick) to move a ball. With the aim of creating as many goals as possible against the opponent's goal and keeping the net himself from conceding the ball. Hockey is divided into 3 types, namely ice hockey, field hockey and indoor hockey. The hockey sports that are developing in Indonesia are field hockey and indoor hockey. Indoor hockey is a sport with a fast playing style, passing the ball quickly, working the ball, running fast towards the opponent's goal and trying to get the ball into the opponent's goal. According to (Purnomo, 2019) in the game of hockey, the most important thing in hockey is the ability to score goals. Because in a match, one of the teams is declared the winner if it has a more goal difference than the opposing team. The indoor hockey game is also considered to have the character of a fast and high intensity match (Karim, Hasan, \& Juniarsyah, 2017). It can be seen from the alternation between the two teams to attack and defend the area of defense. Agreeing with Karim, Latifah revealed that indoor hockey is a high-intensity sport played in teams (Latifah, Margawati, \& Rahadiyanti, 2019).

Hockey is a game played by 2 teams, each team holding a $5 \mathrm{~cm}$ wide bent stick called a stick to move, dribble, control and hit the ball. The form of indoor hockey game is almost the same as futsal, which is making goals against the opponent's goal. Each team consists of 6 players, namely 1 goalkeeper and 5 forwards. This game uses a ball as small as a tennis ball measuring $5.5-5.75$ ounces, and players must not block the opponent with a body or stick (Febrihan, 2019).

Indoor hockey was played on a smaller scale than field hockey. Hockey games have equipment that is used during the game. In the rules of indoor hockey (Hockey, 2019), it is said that indoor hockey is a game played with blocks on the right and left of the field. The number of players in each team is 12 players. 6 core players and 7 reserve players. Room hockey game time is $2 \times 20$ 


\section{Study of Body Attitude Criteria of Indoor Hockey Players Based on Body Height to Obtain Accurate Shooting Techniques}

minutes for the male and female categories. For hockey, the field space used is $36-44$ and 18 - 22 meters wide with a radius of 9 meters and a penalty point of 7 meters. The size of the hockey goal for the room is 3 meters long and 2 meters wide. In the journal (Vinson et al., 2013) hockey is a six x six game most commonly played in a sports hall on a $44 \times 22 \mathrm{~m}$ pitch with two, 0.10 $\mathrm{m}$ high boards running down each touchline to keep the ball in play.

Hockey players are required to master the basic techniques of playing indoor hockey correctly, in order to be able to continue from basic technical skills to advanced hockey techniques so that they are able to master complex techniques. Mastery of the correct basic techniques will really help a player and is a mandatory thing that hockey players must really master (Ramdhan \& Sunaryadi, 2019). Mastering the basic techniques of playing indoor hockey cannot be obtained automatically, but through a process that is deliberately formed, planned, systematic coaching, carried out and evaluated continuously, carried out in a planned, structured, systematic and tiered manner. So that they can knoow completely every basic technique of the game of indoor hockey. According to (Febrihan, 2019). Indoor hockey players must be played basic techniques that can make it easier to flow the ball or arrange attacks so they can score goals. The basic techniques in the hockey game that players know include handling, dribbling, pushing the ball, receiving, controlling the ball, and grabbing the ball. From some of the quotes above, it can be concluded that the basic techniques that every Indonesian indoor hockey athlete must know, namely griping, passing the ball, dribbling, holding or receiving the ball, and shooting the ball.

From Febrihan, according to (Drs. IWAN BARATA, 2020) in the book Theory and Practice of Hockey Sports, the basic hockey game techniques that must be mastered, namely how to hold hockey sticks (gripping), play the ball in place (dodging), dribble (dribbling) ), pushing the ball (push), stopping the ball (stopping), pushing the ball with a reverse stick push (tapping), hitting the ball with a reverse stick (reverse stick tap), hitting the ball (hit), hitting with a low stick or slap, flick, scoop and reverse stick hit or tomahawk which are the newest techniques, but in room hockey the basic techniques must be mastered only griping, dodging, dribbling, stoping, push (passing and shooting).

Shooting skills in indoor hockey are part of the basic technique that is important for all athletes. Because do a good shooting skills, an indoor hockey athlete can help contribute by doing a lot of shooting attempts at the opponent's goal to create opportunities for the team to score goals. To achieve a victory requires a game tactic and strategy, therefore good basic technical skills are needed (TRI ATMOJO \& BULQINI, 2019). Shooting towards the goal that is done by indoor hockey athletes is not easy, because in every goal there is a player who is specially tasked with guarding the goal who allows holding the ball using his hands. To create a goal opportunities against the opponent's goal, a hockey player must have an accurate shooting technique in order to aim at the goal. Without doing a shooting experiment, indoor hockey games will not be interesting, because only shooting goals can be created.

Anthropometry is widely applied in the field of sports, according to (Waluyo, 2012) body posture and body parts owned by each athlete are one of the factors that influence sports performance. In several sports, high posture with ideal body weight and good physical condition will support the achievement of high sports achievements.

Anthropometry is useful for knowing the structure of a person's body and can place on what branch is suitable for that person. The goal is to create a professional player seen from the adequate body structure of his bodily functions. In sports, anthropometry is needed to maximize an achievement as the role of anthropometry in various sports, from determining sports that can maximize the condition of athletes (Dewi, 2017).

The anthropometric factor of an athlete has an important role in the sport he is engaged in, so that it will affect achievement. In this case, (Rustanto, 2015) states that "one of the aspects in achieving achievement in sports is a biological aspect which includes body structure and posture, namely: (1) height and leg length; (2) size, width, and weight; (3) somatotype (body shape). Meanwhile, according to (Waluyo, 2012), biological aspects in the form of body structure and posture such as height and weight are one of the determinants of ability achievement in sports, height and weight can significantly affect success in sports depending on how each sport is followed. It can be concluded that in indoor hockey, body weight and height are important aspects of sports achievement. The ideal height and weight have an important role in indoor hockey because each player must have speed, agility, be able to change positions quickly, stop spontaneously, and move continuously so that every player is required to have the ideal body weight. make it easier to move.

\section{METHOD}

Qualitative research is a study aimed at describing and analyzing phenomena, events, social activities, attitudes, beliefs, perceptions, thoughts of individuals and groups (Bachri, 2010). This study aims to describe the shooting technique in indoor hockey based on height. This research also made a questionnaire to find out the participants' responses. the questionnaire was created through the google form with indicators of playing experience, playing knowledge, hockey time, height, arm length, and distance between handies. 


\section{Study of Body Attitude Criteria of Indoor Hockey Players Based on Body Height to Obtain Accurate Shooting Techniques}

\section{RESULT AND DISCUSSION}

This questionnaire contains statements about the indoor hockey shooting technique that has been implemented. The questionnaire that has been made received a positive response where the questionnaire was filled out by athletes.

On the indicator of playing experience we can see that the first statement "playing experience greatly affects the skills of accurate shooting techniques". Of the $100 \%$ responses that came in, $45 \%$ answered strongly agree, $44 \%$ answered agree, $7 \%$ answered doubtful, $4 \%$ answered disagree.

In the second statement "the more experience playing, the better the accuracy of the shooting technique that is owned". In the second statement "the more experience playing, the better the accuracy of the shooting technique that is owned".

In the third statement "accurate shooting technique is not obtained from playing experience". Of the $100 \%$ responses that came in $11 \%$ answered strongly agree, 33\% answered agree, $15 \%$ answered doubtfully, 30\% answered disagree, and $11 \%$ answered strongly disagree.

In the fourth statement "Playing experience does not determine the accuracy of a player's shooting technique". Of the $100 \%$ responses that came in $0 \%$ answered strongly agree, $33 \%$ answered agree, $11 \%$ answered doubtfully, $45 \%$ answered disagree, and $11 \%$ answered strongly disagree.

In the indicator of knowledge, "Accurate shooting technique is influenced by comfort in holding the stick". Of the $100 \%$ responses that came in, 52\% answered strongly agree, $44 \%$ answered agree, $4 \%$ answered doubtfully, $0 \%$ answered disagree, and $0 \%$ strongly disagreed.

In the second statement "Posture determines the accuracy of a player's shooting technique". Of the $100 \%$ responses that came in, $70 \%$ answered strongly agree, $30 \%$ answered agree, $0 \%$ answered doubtfully, $0 \%$ answered disagree, and $0 \%$ strongly disagreed.

In the third statement "The better the player's knowledge of hockey, the better the accuracy of his shooting technique". Of the $100 \%$ responses that came in $33 \%$ answered strongly agree, $45 \%$ answered agree, $11 \%$ answered doubtfully, $11 \%$ answered disagree, and $0 \%$ answered strongly disagree

In the fourth statement "Playing knowledge does not affect the accuracy of a player's shooting technique". Of the $100 \%$ responses that came in $4 \%$ answered strongly agree, 30\% answered agree, $18 \%$ answered doubtful, $41 \%$ answered disagree, and $7 \%$ answered strongly disagree

On the height indicator we can see that the first statement "Height affects the accuracy of a player's shooting technique". Of the $100 \%$ responses that came in, $11 \%$ answered strongly agree, $19 \%$ answered agree, $26 \%$ answered doubtfully, $44 \%$ answered disagree, and $0 \%$ strongly disagreed.

In the second statement "The taller the player, the better the accuracy of his shooting technique". Of the $100 \%$ responses that came in, $0 \%$ answered strongly agree, $8 \%$ answered agree, $37 \%$ answered doubtfully, $48 \%$ answered disagree, and $7 \%$ strongly disagree.

In the third statement "The accurate shooting technique is not determined by the height of the player". Of the $100 \%$ responses that came in $4 \%$ answered strongly agree, 52\% answered agree, 22\% answered doubtfully, 22\% answered disagree, and 0\% answered strongly disagree

In the arm length indicator we can see that the first statement "The skill of accurate shooting technique is affected by the length of the arm". Of the $100 \%$ responses that came in, $7 \%$ answered strongly agree, $7 \%$ answered agree, $41 \%$ answered doubtfully, $45 \%$ answered disagree, and $0 \%$ strongly disagreed.

In the second statement "The longer a hockey player's arm, the better the accuracy of his shooting technique". Of the $100 \%$ responses that came in, $4 \%$ answered strongly agree, 15\% answered agreed, 33\% answered doubtfully, 44\% answered disagree, and $4 \%$ strongly disagreed

In the third statement "The length of a player's arm determines the accuracy of the shooting technique". Of the $100 \%$ responses that came in $4 \%$ answered strongly agree, $11 \%$ answered agree, 33\% answered doubtfully, $48 \%$ answered disagree, and $4 \%$ answered strongly disagree.

In the fourth statement "accurate shooting technique is not derived from the length of a player's arm". Of the $100 \%$ responses that came in $7 \%$ answered strongly agree, 44\% answered agree, 30\% answered doubtfully, 19\% answered disagree, and 0\% answered strongly disagree 


\section{Study of Body Attitude Criteria of Indoor Hockey Players Based on Body Height to Obtain Accurate Shooting Techniques}

On the indicator of the distance between the handles we can see that the first statement "The accurate shooting technique is affected by the distance between the handles". Of the $100 \%$ responses that came in, $19 \%$ answered strongly agree, $59 \%$ answered agree, $22 \%$ answered doubtfully, $0 \%$ answered disagree, and $0 \%$ strongly disagreed.

In the second statement "The farther the distance between the hands, the better the shooting technique accuracy of a player". Of the $100 \%$ responses that came in, $11 \%$ answered strongly agree, $22 \%$ answered agree, $41 \%$ answered doubtfully, $26 \%$ answered disagree, and $0 \%$ strongly disagreed

In the third statement "The distance between the hands determines the accuracy of a player's shooting technique". Of the $100 \%$ responses that came in $22 \%$ answered strongly agree, $48 \%$ answered agree, $22 \%$ answered doubtfully, $8 \%$ answered disagree, and $0 \%$ answered strongly disagree

In the fourth statement "accurate shooting technique is not derived from the length of a player's arm". Of the $100 \%$ responses that came in 33\% answered strongly agree, 56\% answered agree, $4 \%$ answered doubtfully, $7 \%$ answered disagree, and $0 \%$ answered strongly disagree.

\section{CONCLUSIONS}

Based on the results of the analysis and discussion, it can be concluded that playing experience, comfort, attitude The body of the respondents supports the ability to shoot an accurate ball, respectively, shown by the percentage strongly agree and agree are $45 \%$ and $44 \%, 52 \%$ and $44 \%, 70 \%$ and $30 \%$.

Furthermore, for height, the largest percentage was $44 \%$ disagreed and $26 \%$ doubtful, for arm length the largest percentage was $45 \%$ doubtful and $41 \%$ disagreed. This means that height and arm length do not affect the accuracy of respondents on receiving ball. However, the distance between the hand grips affects the accuracy and comfort, this is reinforced by the percentage strongly agree and agree that the hand grip distance affects the accuracy is $19 \%$ and $59 \%$ and the distance between the handles based on comfort is $33 \%$ and $56 \%$.

\section{REFERENCES}

1) Bachri, B. S. (2010). Meyakinkan Validitas Data Melalui Triangulasi Pada Penelitian Kualitatif. Teknologi Pendidikan, $10,46-62$.

2) Dewi, U. (2017). Kemampuan Daya Loncat Dan Smash Pada Atlet Bolavoli Putri. Jurnal Pendidikan Olahraga, 6(2), 8795

3) Drs. IWAN BARATA, M. P. (2020). Teori dan Praktek Olahraga Hoki.

4) Febrihan, A. S. E. R. (2019). KONTRIBUSI KELINCAHAN DAN KEKUATAN OTOT LENGAN TERHADAP KETERAMPILAN INDIAN DRIBBLE PADA SISWA EKSTRAKURIKULER HOCKEY DI SMA NEGERI 1 MENGANTI. Jurnal Kesehatan Olahraga, 07(02), 367-372.

5) Hockey, F. I. (2019). Rules of Indoor Hockey. 1-70.

6) Istofian, R. S., \& Amiq, F. (2016). Metode Drill Untuk Meningkatkan Teknik Menendang Bola (Shooting ) Dalam Permainan Sepakbola Usia 13-14 Tahun. Jurnal Kepelatihan Olahraga, 1(1), 105-113.

7) Karim, D. A., Hasan, M. F., \& Juniarsyah, A. D. (2017). Analisis Ketepatan Hasil Pukulan Normal Grip dan Short Grip dalam Permainan Hockey untuk Atlet Pemula. Keolahragaan, 5(2), 36.

8) Latifah, N. N., Margawati, A., \& Rahadiyanti, A. (2019). Hubungan komposisi tubuh dengan kesegaran jasmani pada atlet hockey. Jurnal Keolahragaan, 7(2), 146-154. https://doi.org/10.21831/jk.v7i2.2808 5

9) Lestari, Y. N. A., \& Amin, N. (2019). Hubungan Status Gizi, Tingkat Kecukupan Energi Dan Zat Gizi Dengan Kecepatan Pada Atlet Hockey Kota Surabaya. Sport and Nutrition Journal, 1(1), 19-26. https://doi.org/10.15294/spnj.v1i1.31 275

10) Maulana Misfajar, S. (2019). ANALISIS ANTROPOMETRI DAN KONDISI FISIK PEMAIN BOLABASKET PUTRA. INDONESIA PERFORMANCE JOURNA, 2(1), 8- 12

11) Ramdhan, M. R., \& Sunaryadi, Y. (2019). Perbandingan Latihan Medicine Ball Side Throw dengan Kettlebell Side Swing terhadap Peningkatan Kecepatan Hit Cabang Olahraga Hockey. Jurnal Kepelatihan Olahraga, 11(2), 83-87. Retrieved from https://ejournal.upi.edu/index.php/JK O/article/view/20313/10237

12) Sharma, A., Tripathi, V., \& Koley, S. (2012). Correlations of anthropometric characteristics with physical fitness tests in Indian professional hockey players. Journal of Human Sport and Exercise, 7(3), 698-705.

https://doi.org/10.4100/jhse.2012.73.0 